\title{
Non-syndromic oral clefts and risk of cancer: a systematic review
} \author{
Júnior ${ }^{1}$ \\ ${ }^{1}$ Department of Dentistry, State University of Montes Claros, Montes Claros, Minas Gerais, Brazil. \\ ${ }^{2}$ Department of Medicine, State University of Montes Claros, Montes Claros, Minas Gerais, Brazil. \\ ${ }^{3}$ Department of Periodontology and Oral Implantology, Rural Dental College, Ahmednagar, Maharashtra, India. \\ ${ }^{4}$ Department of Oral Diagnosis, Piracicaba Dental School, University of Campinas, Piracicaba, São Paulo, Brazil.
}

Daniela Araújo Veloso Popoff ${ }^{1}$, Mateus Prates Coelho ${ }^{2}$, Daniella Reis Barbosa Martelli ${ }^{1}$, Rajiv Saini ${ }^{3}$, Ricardo Della Coletta ${ }^{4}$, Hercílio Martelli-

\section{Abstract}

Objective: To discuss the risk of cancer among relatives of individuals with cleft lip and palate $(\mathrm{CL} / \mathrm{P})$, as well as the risk of $\mathrm{CL} / \mathrm{P}$ among relatives of individuals with cancer, since studies currently published have suggested an increased risk of cancer among relatives of individuals with clefts.

Methods: A systematic literature review was carried out in accordance with the Cochrane Collaboration Group protocol, including literature search strategy, selection of papers through the inclusion and exclusion criteria, data extraction and quality assessment. PubMed, Scopus and ISI - Web of Science databases were systematically searched using the following search strings: "cleft lip and palate" AND "cancer," "oral clefts" AND "cancer" and "orofacial clefts" AND "cancer."

Results: From 653 studies accessed, eight comprised the final sample: six investigating CL/P index cases and their family history of cancer and two investigating individuals with cancer and their family history for $\mathrm{CL} / \mathrm{P}$. The sample sizes were not homogeneous. Oral clefts, the type of cancer and the degree of kinship family were not categorized in all studies. Leukemia, breast cancer and colon cancer were the most cited types, even as first- and seconddegree relatives.

Conclusion: An increased risk of cancer among relatives of individuals with clefts could not be entirely confirmed. However, studies with this specific purpose suggest that first- and second-degrees relatives of individuals with cleft have some types of cancer more often than unexposed families, highlighting that future studies should expand their samples to investigate possible common molecular mechanisms that allow relating oral clefts and cancer.

\section{Introduction}

Orofacial malformations are the most common form of congenital anomalies in the world [1]. Among the orofacial alterations, the most prevalent is the cleft lip with or without cleft palate (CL/P) [2-5], which may occur more commonly in an isolated and non-syndromic form as a specific phenotype or, more rarely, composing several associations or syndromes [6,7]. Embryologically, clefts result from primary fusion defects of the craniofacial processes that form the primary and secondary palate in the first intrauterine trimester [8].

The incidence of $\mathrm{CL} / \mathrm{P}$ varies according to geographical location, racial and ethnic groups, environmental exposures, and socioeconomic status, affecting approximately $1 / 700$ live births with wide variability across geographic origin. Generally, Asian and Amerindian populations have the highest reported birth prevalence rates, often as high as $1 / 500$, European-derived populations have intermediate prevalence rates at about 1/1000, and African-derived populations have the lowest prevalence rates at about $1 / 2500[5,9,10]$.

According to Vieira (2008) [7], the last decade was crucial to elucidate issues concerning the etiology of CL/P when compared to other defects observed at birth. As this is a multifactorial trait, environmental risk factors such as smoking, alcohol, parental age,
Citation: Popoff DAV, Coelho MP, Martelli DRB, Saini R, Coletta RD, and Martelli-Junior H. (2013) Nonsyndromic oral clefts and risk of cancer: a systematic review. Dentistry 3000 1:a002 doi: 10.5195/d3000.2013.11

Received: June 24, 2013

Accepted: August 12, 2013

Published: August 23, 2013

Copyright: (02013 Popoff et al. This is an open-access article licensed under a Creative Commons Attribution 3.0 United States License.

Email: danielavelloso@yahoo.com.br medications, birth order, interpregnancy interval, and folic acid deficiency are listed as modifiers, and risk factor identification is the first step to better understanding and to prevent such craniofacial changes $[7,11,12]$. However, current knowledge about the causes of CL/P points particularly towards genetic risk factors, and the study of the pathogenesis of $\mathrm{CL} / \mathrm{P}$ has provided ample opportunities to identify candidate genes for this disorder and even link them to the occurrence of cancer in relatives of individuals born with $\mathrm{CL} / \mathrm{P}$, or even in these individuals themselves when at an adult age, supporting the hypothesis that common genetic factors may be present in both conditions [13]. Although other genes that have

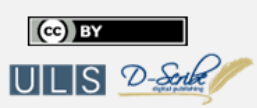

This work is licensed under a Creative Commons Attribution 3.0 United States License.

This site is published by the University Library System, University of Pittsburgh as part of its D-Scribe Digital Publishing Program and is cosponsored by the University of Pittsburgh Press. 
not been explored yet can be involved in the both conditions, three genes are suspected to underlie such associations: FGF - fibroblast signaling pathway, CDH1 - epithelial cadherin and AXIN2 - AXIS inhibition protein 2 [14]. Colorectal and breast cancer are the most associated with mutations of these genes [2].Thus, given the growing number of studies published currently suggesting a common etiology for CL/P and cancer and increased risk of cancer among relatives of cleft individuals [2,5,13-18], the current study aimed to discuss the issue through a systematic literature review in order to provide additional evidence of these genetic risks, which will aid in the development of strategies that target more aggressive screening programs and preventive chemical treatments.

\section{Methods}

The present review was carried out in accordance with the Cochrane Collaboration Group protocol for systematic reviews [19], including a literature search strategy, selection of papers through the inclusion and exclusion criteria, data extraction, and quality assessment. Meta-analysis was not possible since selected studies did not observe the same variables, methods, participants, and outcomes, which prevented comparisons.

\section{Literature search strategy}

Our review was performed in February 2013 in order to obtain literature regarding cleft lip and/or palate and family history of cancer. PubMed, Scopus, and ISI - Web of Science databases were systematically searched using two basic approaches: the search strings "cleft lip and palate" AND "cancer," "oral clefts" AND "cancer," and "orofacial clefts" AND "cancer" for studies published up to that time.

Selection of papers through the inclusion and exclusion criteria

The selection of papers is diagrammatically explained in Figure 1. Of the 653 studies originally found through the literature search strategy, 235 studies were excluded (in non-English language, with no full text available, and non-cross-sectional, prevalence, cohort, or case-control design), remaining with 418 papers. Additional studies were found through the references of the potential studies retrieved. Then, all studies involving oral clefts (associated or not with craniofacial syndromes or any anomalies) and cancer were selected. Afterwards, only studies presenting information regarding

Figure 1: Flowchart of the studies included and excluded

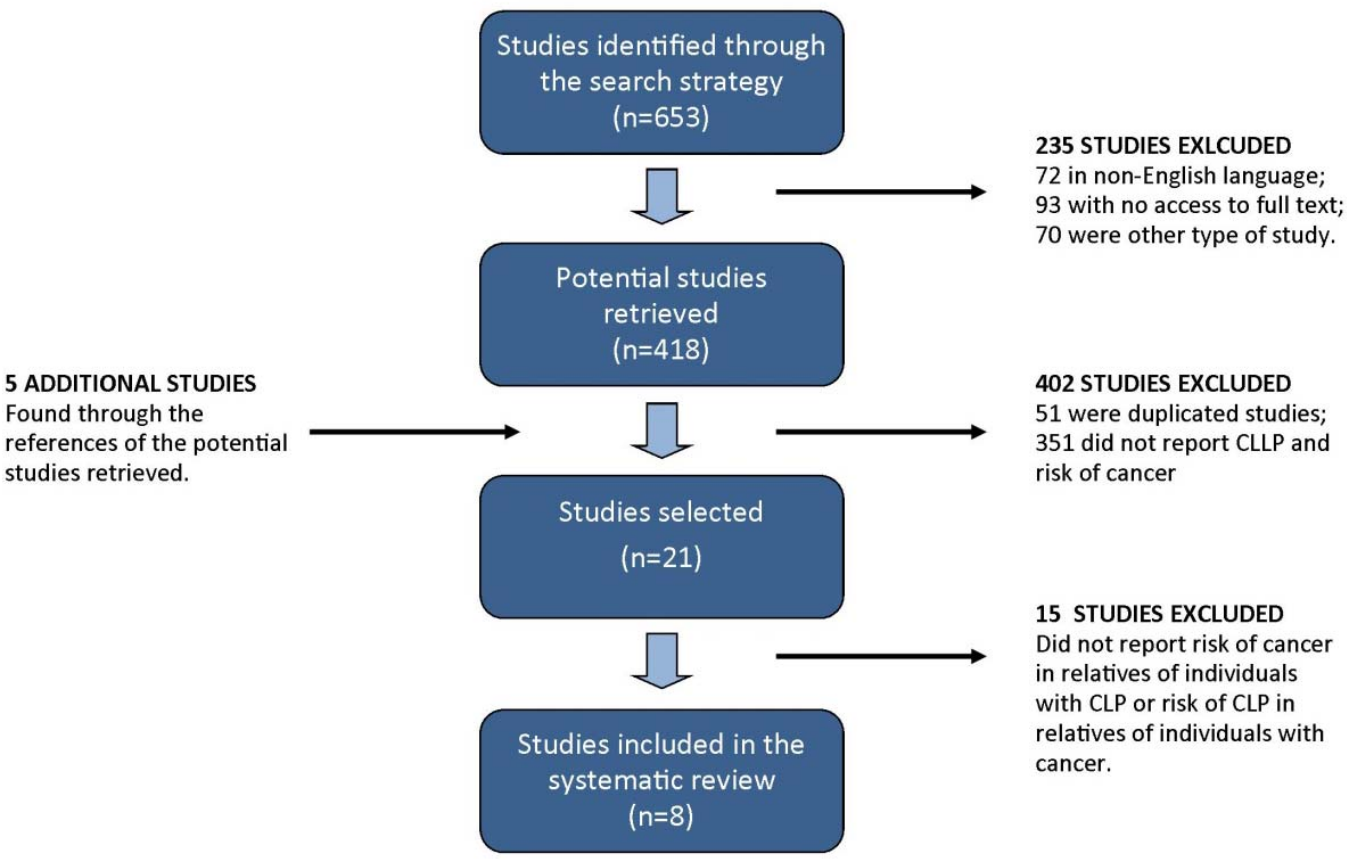

risk of cancer in relatives of individuals born with non-syndromic oral clefts were included in the present study, as well as articles regarding the frequency of nonsyndromic oral clefts among relatives of individuals diagnosed with cancer.

The following specific inclusion criteria were used to identify relevant articles: (1) Index cases with non-syndromic cleft lip and/or palate, whose relatives were investigated for any type of cancer; (2) Index cases with any type of cancer, whose relatives were investigated for non-syndromic cleft lip and/or palate; (3) Index cases compared to healthy controls for risk assessment; (4) The degree of relationship between index cases and investigated family members is investigated in the study. All studies that included individuals with cleft lip and/or palate associated with other abnormalities, having syndromic causes or regarding Mendelian traits were excluded. Thus, eight studies were selected. (Figure 1)

\section{Data extraction}

Title and abstract screening was performed by two reviewers (DAVP and HMJ) who worked independently to identify potentially relevant papers for which full text publications were retrieved. If, however, there was any discrepancy of opinion, the reviewers reexamined the paper together and arrived at a joint final decision. A standardized form was used to extract information, such as author and year of publication of the paper, origin of participants, study design, sample size, type of oral clefts, type of cancer, degree of kinship of family members and the association between non-syndromic oral clefts and cancer.

\section{Quality assessment}

STROBE methodology (Strengthening the Reporting of Observational Studies in Epidemiology) [20], considered the guideline for an appropriate assessment of observational studies, was used to perform the quality assessment of the studies selected. The specific STROBE items considered were inclusion and exclusion criteria, assessment of exposure and outcome, statistical methods, confounders, bias, and report limitation.

\section{Results}

The initial database search identified 653 citations published between 1980 and 2013 . After screening, 235 studies were excluded (72 in non-English language, 93 with no full text available, and 70 which type of study was other than those listed in the methodology), remaining with 418 papers.

A second screening was performed on the remaining papers and other studies were excluded, this time for the following reasons: 51 articles in duplicity (found in more than one of the databases) and 351 articles that did not report non-syndromic cleft lip and/or palate and risk of cancer. In addition, five papers listed in the references of the selected ones were included, resulting in 21 papers for the final screening. 


\begin{tabular}{|c|c|c|c|c|c|c|c|c|c|}
\hline $\begin{array}{c}\text { First author, } \\
\text { year } \\
\text { [reference] }\end{array}$ & $\begin{array}{l}\text { Country } \\
\text { of study }\end{array}$ & Study design & Exposure & $\begin{array}{c}\text { Sample size } \\
\text { (case/population) }\end{array}$ & $\begin{array}{c}\text { Cleft } \\
\text { Classification }\end{array}$ & $\begin{array}{l}\text { Type of } \\
\text { cancer }\end{array}$ & $\begin{array}{c}\text { Statistical } \\
\text { test }\end{array}$ & $\begin{array}{l}\text { Kinship with } \\
\text { index cases }\end{array}$ & Outcome \\
\hline $\begin{array}{c}\text { Jindal, } \\
2012\end{array}$ & India & Case-control & $\begin{array}{l}\text { Individuals } \\
\text { diagnosed } \\
\text { with cancer }\end{array}$ & $142(85 / 57)$ & $\mathrm{CL} / \mathrm{P}$ & Leukemia & $\begin{array}{c}\mathrm{X} 2 \text { and Fischer } \\
\text { exact }\end{array}$ & First-degree & Increased risk \\
\hline $\begin{array}{l}\text { Yildirim, } \\
2012\end{array}$ & Turkey & Case-control & $\begin{array}{c}\text { Cleft } \\
\text { individuals }\end{array}$ & $319(158 / 161)$ & All & Unspecified & $\begin{array}{l}\text { Logistic } \\
\text { regression }\end{array}$ & First-degree & Increased risk \\
\hline $\begin{array}{c}\text { Menezes } \\
2009\end{array}$ & $\begin{array}{l}\text { United } \\
\text { States }\end{array}$ & Case-control & $\begin{array}{c}\text { Cleft } \\
\text { individuals }\end{array}$ & $168(75 / 93)$ & Unspecified & Unspecified & $\begin{array}{c}\mathrm{X} 2 \text { and Fischer } \\
\text { exact }\end{array}$ & Not reported & Increased risk \\
\hline $\begin{array}{l}\text { Zhu, } \\
2002\end{array}$ & Denmark & Case-control & $\begin{array}{c}\text { Cleft } \\
\text { individuals }\end{array}$ & $41206(45 / 41161)$ & Unspecified & Unspecified & Odds Ratio & First Degree & Increased risk \\
\hline $\begin{array}{c}\text { Vieira, } \\
2012 \\
\end{array}$ & Latvia & $\begin{array}{c}\text { Cross- } \\
\text { sectional }\end{array}$ & $\begin{array}{c}\text { Cleft } \\
\text { individuals }\end{array}$ & 89 & Unspecified & Unspecified & Risk Ratio & $\begin{array}{l}\text { First/second/ } \\
\text { third-degree }\end{array}$ & Increased risk \\
\hline $\begin{array}{l}\text { Dietz, } \\
2012\end{array}$ & Denmark & $\begin{array}{l}\text { Retrospec- } \\
\text { tive cohort }\end{array}$ & $\begin{array}{c}\text { Cleft } \\
\text { individuals }\end{array}$ & 1809 & All & $\begin{array}{l}\text { Breast } \\
\text { Cancer }\end{array}$ & Cox regression & First-degree & $\begin{array}{l}\text { No association } \\
\text { when all non- } \\
\text { syndromic } \\
\text { CL/P were } \\
\text { analyzed } \\
\text { together }\end{array}$ \\
\hline $\begin{array}{c}\text { Steinwachs, } \\
2000\end{array}$ & $\begin{array}{l}\text { United } \\
\text { States }\end{array}$ & $\begin{array}{c}\text { Cross- } \\
\text { sectional }\end{array}$ & $\begin{array}{c}\text { Cleft } \\
\text { individuals }\end{array}$ & 196 & $\mathrm{CL} / \mathrm{P}$ and $\mathrm{CL}$ & Unspecified & Odds Ratio & $\begin{array}{c}\text { First/second- } \\
\text { degree }\end{array}$ & $\begin{array}{c}\text { No increased } \\
\text { risk }\end{array}$ \\
\hline
\end{tabular}

The full text of these papers was read and 13 were there after excluded for not reporting risk of cancer in relatives of individuals with non-syndromic cleft lip and/or palate, as well as for not reporting the frequency of non-syndromic cleft lip and/or palate in relatives of individuals diagnosed with cancer. Thus, eight papers were selected for the systematic review.

Table 2: Most cited types of cancer among relatives of cleft individuals and cancer index cases.

\begin{tabular}{|c|c|c|}
\hline $\begin{array}{l}\text { First author, year } \\
\text { [reference] }\end{array}$ & Most commonly found types of cancer & $\begin{array}{l}\text { Types of cancer with increased } \\
\text { risk at index cases relatives }\end{array}$ \\
\hline Jindal, 2012 & Leukemia* & Leukemia \\
\hline Taioli, 2010 & Breast, colon-rectal, melanoma, testicular & $\begin{array}{l}\text { Testicular, melanoma, colon- } \\
\text { rectal }\end{array}$ \\
\hline Yildirim, 2012 & Unspecified & Unspecified \\
\hline Menezes, 2009 & Unspecified & Unspecified \\
\hline Zhu, 2002 & $\begin{array}{l}\text { Breast, melanoma of skin, testis, cervix uteri, } \\
\text { brain and nervous system }\end{array}$ & Lymphoma, Leukemia \\
\hline Vieira, 2012 & Unspecified & Unspecified \\
\hline Dietz, 2012 & Breast* & Breast \\
\hline Steinwachs, 2000 & Breast, lung, leukemia, colon, uterine. & None found \\
\hline
\end{tabular}

*The study specifically searched for this type of cancer only.
The characteristics of the eight selected papers are presented in Table 1. Three used a case-control design, two used a crosssectional/prevalence design and one was a retrospective cohort study. Those reporting frequency of non-syndromic cleft lip and/or palate in relatives of individuals diagnosed with cancer also used a case-control design.

The sample sizes and the population investigated varied considerably amongst the studies, not being homogeneous. From those investigating risk of cancer in relatives of individuals with non-syndromic cleft lip and/or palate, two were conducted in the United States, two in Denmark, one in Turkey, and one in Latvia. Regarding those reporting frequency of non-syndromic cleft lip and/or palate in relatives of individuals diagnosed with cancer, one was conducted in the United States and one in India (Table 1).

Most of studies investigated all types of oral clefts. Type of cancer and the degree were not categorized in all studies of kinship in the family. Despite this, leukemia, testicular cancer, melanoma, colon-rectal cancer, lymphoma, and breast cancer were the most cited types of cancer (Table 2) in both firstand second-degree relatives (Table 1).

The relationship between oral clefts and cancer within the studies was tested using chi-square and Fisher's Exact tests $[14,18]$, Logistic regression $[2,17]$, Odds ratio $[15$, 21], Risk ratio [13], and Cox regression [5] (Table 1).

All eight studies were submitted to quality assessment using STROBE guidelines. Inclusion and exclusion criteria were described in all of them (Table 3). The outcomes of two studies provide suggestive evidence that families with individuals diagnosed with some types of cancer report family history of cleft lip and/or palate more frequently than families without cases 
Table 3: Inclusion and exclusion criteria among the eight selected papers

\begin{tabular}{|c|c|c|}
\hline $\begin{array}{l}\text { First author, } \\
\text { year } \\
\text { [reference] }\end{array}$ & Inclusion Criteria & Exclusion Criteria \\
\hline Jindal, 2012 & $\begin{array}{l}\text { All subjects were children being cared for at the General Hospital of Chandigarh, India. Cases } \\
\text { were identified from the Pediatric Leukemia Clinic and controls were identified randomly } \\
\text { from the Allergy/Immunology clinic. }\end{array}$ & $\begin{array}{l}\text { Children with lymphoma were excluded from the } \\
\text { case group and the ones with positive history for } \\
\text { cancer, from the control group. }\end{array}$ \\
\hline Taioli, $\quad 2010$ & $\begin{array}{l}\text { Case group was composed of patients who were treated for cancer in the past, who were } \\
\text { considered in remission for at least six months, and who were scheduled for an appointment } \\
\text { for a routine checkup. Control group was composed by healthy people from the general } \\
\text { population who were } 18 \text { years of age or older. }\end{array}$ & Not reported. \\
\hline Yildirim, 2012 & $\begin{array}{l}\text { All subjects were patients at the Department of Pedodontics clinic, Istanbul University, Tur- } \\
\text { key. Case group was composed of individuals born with any type of } \mathrm{CL} / \mathrm{P} \text { and controls were } \\
\text { individuals unrelated to them. Case group members' first-degree relatives were evaluated, } \\
\text { also. }\end{array}$ & Case and control siblings were excluded. \\
\hline $\begin{array}{l}\text { Menezes, } \\
2009\end{array}$ & $\begin{array}{l}\text { All subjects were from white ancestry families from Pittsburgh. Cases were recruited from a } \\
\text { registry maintained by the Cleft-Craniofacial Center, Children's Hospital of Pittsburgh of } \\
\text { UPMC. }\end{array}$ & Not reported. \\
\hline Zhu, 2002 & $\begin{array}{l}\text { Subjects were identified from the Denmark's Central Population Registry by their kinship with } \\
\text { patients diagnosed with cancer and registered at the Cancer Registry. They also ought to } \\
\text { have been born between } 1977 \text { and } 1995 \text { in Denmark to mothers with a Danish citizenship. }\end{array}$ & $\begin{array}{l}\text { Patients whose parents had other children be- } \\
\text { fore 1977, who were diagnosed with patent } \\
\text { ductus arteriosus, undescended testis and hip } \\
\text { dislocation. }\end{array}$ \\
\hline Vieira, 2012 & $\begin{array}{l}\text { Subjects were picked from the Riga Cleft Lip and Palate Centre Registry from the time period } \\
\text { of } 1980-2009 .\end{array}$ & Not reported. \\
\hline Dietz, 2012 & $\begin{array}{l}\text { Subjects were individuals with non-syndromic } \mathrm{CL} / \mathrm{P} \text { registered at the Danish Facial Cleft Regis- } \\
\text { ter. }\end{array}$ & Individuals born after 1975 were excluded. \\
\hline $\begin{array}{l}\text { Steinwachs, } \\
2000\end{array}$ & $\begin{array}{l}\text { Subjects ought to have been diagnosed with cleft lip with or without cleft palate and have no } \\
\text { known syndromal cause for the cleft. }\end{array}$ & Not reported. \\
\hline
\end{tabular}

of cancer [2,18]. From studies investigating cancer in relatives of individuals with oral clefts, only two suggest that the first- and second-degree relatives of the individuals with clefts are not at an increased risk for cancer $[5,21]$. All studies defined the exposure variables (Table 1). Although all studies had described potential bias/limitations, only three properly reported identification of bias/limitations (Table 1). Although all studies had described potential bias/limitations, only three properly reported identification of bias/limitations (Table 4).

\section{DISCUSSION}

This systematic review assessed available studies suggesting a common etiology for non-syndromic oral clefts and cancer and increased risk of cancer among relatives of cleft individuals, as well as increased risk of non-syndromic oral clefts among relatives of individuals diagnosed with cancer, thereby providing additional evidence of these genetic risks, which could aid in the development of strategies that target more ag- gressive screening programs and preventive chemical treatments.

Our original intention was to integrate the results of included studies through a metaanalysis, however, given the differences in variables, methods, participants and outcomes among the studies, the most suitable and responsible was to address the issue through a systematic review.

We demonstrated that there is a large amount of literature distinguishing nonsyndromic cleft lip and palate from those cases of clefts associated with other abnormalities, syndromes, or Mendelian traits. Our findings also demonstrated that the studies published agree that non-syndromic oral clefts are one of the most common human malformations, with an average prevalence of 1 per 700 or 1,000 live births [ $2,4,5,7,16,17,21-26]$, as well as that its incidence varies according to gender: 2:1 being the ratio of males to females for cleft lip and palate and 1:2 the approximate ratio of male to female for isolated cleft palate $[1,10,16,26,27]$.
Other common information between the studies is the fact that unilateral clefts are more common than bilateral clefts, and of the unilateral cases of non-syndromic cleft lip and palate, left-sided cleft lips occur more frequently than right-sided cleft lips [ $4,5,21,23,28,29]$. Many studies have also demonstrated that genetic factors may play a role in the cause of non-syndromic oral clefts in addition to certain environmental and/or stochastic factors, meaning that this malformation is a multifactorial trait $[2,21,22,26,30,31]$. Similarly, studies have shown that cleft lip, with or without cleft palate, is entirely different from isolated cleft palate in both embryological and pathogenetic standpoints [32,33].

Likewise, many of the studies report relationships between non-syndromic oral clefts and cancer or childhood cancer $[14,18,25,34-41]$. Nonetheless, the studies that presented information regarding risk of cancer in relatives of individuals born with non-syndromic oral clefts or regarding the frequency of non-syndromic oral clefts 
among relatives of individuals diagnosed with cancer, besides being scarce, vary greatly in their characteristics and designs, precluding a meta-analysis of the results found.

In the current systematic review, both studies assessing the prevalence of CL/P in family members of cancer patients had a casecontrol design and suggest that this malformation is more frequent in families of cancer survivors in comparison with families of a population-based sample of controls. In the study of Taioli et al. (2010) [2], the results were not statistically significant and the authors relate it to the sample size of the study and to the rarity of CL/P occurrence. In the second study, relating $\mathrm{CL} / \mathrm{P}$ and childhood cancer, none of the children from the unaffected group had a positive family history of cleft lip and palate, while five children with leukemia had a positive history of oral clefts [18].

In these studies, the population investigated, or their parents or guardians, answered standardized questionnaires with demographic information about the respondents and their family history of CL/P. It was a consensus between the authors that information on number of second-degree relatives is lacking for both, which could explain their findings for the first-degree relatives, since the more distant the relative is, less information is known about him.

In the study investigating adult individuals who survived cancer, the most frequent types of cancer were melanoma, testicular, breast, colon-rectal, and lymphoma. The authors state, however, that one limitation of the study was to include cancer survivors instead of newly diagnosed cancer patients, which could exclude highly fatal cancers [2].

Despite the different characteristics of the populations investigated in the studies of Taioli et al. (2010) and Jindal and Vieira (2012) $[2,18]$, both suggest that shared genetic factors may explain an association between oral clefts and cancer. Thus, investigating the relationship between malformations and malignancies becomes important as it is speculated that they might have common causes. Endorsing that possibility, Chalothorn et al. (2008) and Küchler et al. (2013) [42,43] have previously proposed an association between tooth agenesis and cancer. In some cases, tooth agenesis and oral cleft may share the same genetic background.

This review also accessed studies [5,13$15,17,21]$ regarding risk of cancer in relatives of individuals born with non- syndromic oral clefts. From the six studies found, three also had a case-control design and more cancer cases were reported among relatives of cleft individuals than by controls [14,15,17]. The most prevalent types of cancer have not been plainly identified in all studies, which was a limitation of the studies declared by the authors. However, in those which it was possible, a clear predominance of colon cancer and leukemia cases was noticed, as well as some reports of breast cancer, lymphoma and brain cancer $[14,15]$. The most affected relatives were specified only in the study of Zhu et al., (2002) [15], which exclusively investigated parents. A further limitation that was found is the fact that the specific data regarding the age of onset of cancer was not accessed, which makes it impossible to determine if family members of individuals with cleft developed cancer at earlier ages than the general population.

A higher prevalence of cancer in family members of individuals born with $\mathrm{CL} / \mathrm{P}$ was presented in a cross-sectional study with a Latvian population, too [13]. The risk was calculated by dividing the prevalence of cancer in the target group by the prevalence of cancer in that population. It was demonstrated that this risk is three times higher in

Table 4: Potential bias/limitations and the author's efforts to identify them among the eight selected papers.

\begin{tabular}{|c|c|c|}
\hline $\begin{array}{l}\text { First author, year } \\
\text { [reference] }\end{array}$ & Bias/limitations & $\begin{array}{c}\text { Identification } \\
\text { of bias/limitations }\end{array}$ \\
\hline Jindal, 2012 & $\begin{array}{l}\text { Information concerning illnesses on relatives more distant than the first-degree } \\
\text { may not be so reliable. }\end{array}$ & Not reported. \\
\hline Taioli, 2010 & $\begin{array}{l}\text { Since it researched cancer survivors and not patients diagnosed with cancer per } \\
\text { se, the most fatal forms of cancer tend to have their association with } \mathrm{CL} / \mathrm{P} \text { not } \\
\text { reported accurately. Also, an association between the type of cancer and } \mathrm{CL} / \mathrm{P} \\
\text { becomes impossible to be made in this case because of characteristic survivor- } \\
\text { ships in each type. }\end{array}$ & Not reported. \\
\hline Yildirim, 2012 & $\begin{array}{l}\text { As information regarding specific types of cancers was not available for all indi- } \\
\text { viduals, an analysis by cancer types could not be done. Also, the specific data } \\
\text { regarding the age of onset of cancer was not accessed, which made it impossible } \\
\text { to determine if family members of cleft individuals developed cancer at earlier } \\
\text { ages than the general population. }\end{array}$ & Not reported. \\
\hline Menezes, 2009 & $\begin{array}{l}\text { The cancer types reported may not all have been related to the same causes. } \\
\text { Also, as there was no access to data that specified the age of cancer develop- } \\
\text { ment in those individuals' family members, it was no possible to determine if } \\
\text { family members of cleft individuals developed cancer at earlier ages than the } \\
\text { general population. }\end{array}$ & $\begin{array}{l}\text { Proposes new research with increased sample size to } \\
\text { replicate findings and test the association between genetic } \\
\text { variants and specific types of cancer. }\end{array}$ \\
\hline Zhu, 2002 & $\begin{array}{l}\text { There may have been some confusion from the teratogenic effects of cancer } \\
\text { treatment in parents who had cancer previous to the child's birth. The outcome } \\
\text { of previous births also could induce some bias as well as maternal age at birth } \\
\text { and sex of the child. Lastly, the lack of data on stillbirths may have biased results } \\
\text { if fetal mortality differs between parents who will develop cancer and parents } \\
\text { who won't. }\end{array}$ & $\begin{array}{l}\text { It only used parents whose cancer diagnostic came up } \\
\text { after the birth of their indexed children. Also, the children } \\
\text { analyzed were only firstborns and the age of the mother at } \\
\text { birth and the child's sex were reported. }\end{array}$ \\
\hline Vieira, 2012 & $\begin{array}{l}\text { The population studied was composed mostly by individuals in their first years of } \\
\text { life, and because of that, the prevalence of pediatric or earlier onset types of } \\
\text { cancer was relatively increased when compared with the other types. The same } \\
\text { is true for their relatives, as they are most likely also relatively young. }\end{array}$ & Not reported. \\
\hline Dietz, 2012 & $\begin{array}{l}\text { A left and right truncation in this study was observed, as no information can be } \\
\text { gotten neither previous nor post the period studied. }\end{array}$ & Not reported. \\
\hline Steinwachs, 2000 & $\begin{array}{l}\text { There is known lack of accuracy in information provided by patient reports about } \\
\text { their family members. }\end{array}$ & $\begin{array}{l}\text { Proposes new and larger studies with sufficient power to } \\
\text { study only first-degree relatives. }\end{array}$ \\
\hline
\end{tabular}


first- and second-degree relatives and decreases to 1.5 times in third-degree relatives. Similar to most available studies with the same proposal, the types of cancer were not consistently reported and, because of that, this study did not discriminate by cancer types.

As well as in the studies addressing prevalence of $\mathrm{CL} / \mathrm{P}$ in family members of cancer patients, findings from four [13-15,17] of six studies regarding risk of cancer in relatives of individuals born with non-syndromic oral clefts provide additional support for a common etiology between CL/P and cancer, suggesting that these families have a higher genetic load for $\mathrm{CL} / \mathrm{P}$, which also impacts their cancer risk.

On the other hand, two other studies regarding risk of cancer in relatives of individuals with clefts could not conclude the same $[5,21]$. The first one, performed by Steinwachs et al., (2000) [21] was emphatic in denying an increased risk for cancer in the first- and second-degree relatives of individual affected with non-syndromic $\mathrm{CL} / \mathrm{P}$. The population investigated was composed of Caucasians, Hispanics, African Americans, and Asian individuals. The cancer data were analyzed in aggregate by type of cancer, by degree of relation to the index case, and by ethnicity. As a result, neither first-degree relatives nor second-degree relatives of the index cases had a significantly increased risk for cancer. No particular ethnic group demonstrated an excessively increased risk for cancer. Not even the most commonly reported cancers (lymphoproliferative cancers, female cancers, and lung cancer) were increased as a whole or in first-degree relatives only.

In the same way, in a recent retrospective cohort study [5] testing whether mothers and sisters of individuals born with $\mathrm{CL} / \mathrm{P}$ have an increased risk for breast cancer, the authors were not able to confirm a general increase in this risk for breast cancer among the study population. However, some associations were revealed when cleft subtype was analyzed, and having a child with isolated cleft palate was associated with an increased risk of breast cancer for the mother, which may be biologically plausible due to the evidence that the different cleft types have different genetic origins $[44,45]$.

Thus, the hypothesis that parental cancer and congenital malformations in offspring may be correlated could not be entirely confirmed by the present systematic review. Despite it being known that possible mechanisms at the basis of an association between $\mathrm{CL} / \mathrm{P}$ and cancer are shared genetic factors, once polymorphisms in genes involved in cell-cell adhesion and cellmotility are associated with both cancer and CL/P $[16,18]$, studies in this direction are very scarce and of those existing and most investigated all subtypes of oral clefts, which sets a limitation to find out such correlation.

There is agreement among almost every reviewed author $[2,14,17,18]$ that the investigated populations in their studies need to be expanded in order to avoid any random findings in multiple testing or the potential impact of Type I error. It is also in agreement that future studies should explore the possibility that there is a preferential occurrence of specific types of cancer in families with individuals born with $\mathrm{CL} / \mathrm{P}$ and test the hypothesis that common genetic and epigenetic mechanisms are playing a role in both conditions $[14,17]$. Through this information, future studies may be better able to identify the causes of nonsyndromic orofacial clefts and ultimately to predict its occurrence and to facilitate genetic counseling of affected families [21]. Another issue raised by Dietz et al. (2012) is the fact that having a cleft leads to social marginalization and changes in lifestyle could predispose not only the individual, but also their family for cancer, which seems plausible from a standpoint of relationship between stress and cancer, as discussed in the literature.

Conflict of interest: There are no conflicts of interest to report.

\section{References}

1. The evolution of human genetic studies of cleft lip and cleft palate. Marazita L M. Annu Rev Genomics Hum Genet. 2012;13:263-83. Epub 2012 Jun 6. PMID:22703175 [PubMed - indexed for MEDLINE]

2. Cleft Lip and Palate in Family Members of Cancer Survivors. Taioli E, Ragin C, Robertson L, Linkov F, Thuman LE, Vieira AR. Cancer Invest. 2010 Nov;28(9):958-62. PMID:20569073 [PubMed - indexed for MEDLINE]

3. Identifying determinants of quality of life of children with cancer and childhood cancer survivors: a systematic review. Klassen AF, Anthony SJ, Khan A, Sung L, Klaassen R. Support Care Cancer. 2011 Sep;19(9):1275-87. Epub 2011 May 25. PMID:21611865 [PubMed - indexed for MEDLINE]

4. Parental age as a risk for non-syndromic oral clefts: a meta-analysis. Herkrath APCQ, Herkrath FJ, Rebelo MAB, Vettore MV. J Dent. 2012 Jan;40(1):3-14.Epub 2011 Oct 13. PMID:22019990 [PubMed - indexed for MEDLINE]

5. Risk of breast cancer in females with cleft lip and palate. Dietz A, Pedersen DA, Jacobsen R, Wehby GL, Murray JC, Christensen K. Ann Epidemiol. 2012 Jan;22(1):37-42. Epub 2011 Oct
28. PMID: 22037380 [PubMed - indexed for MEDLINE]

6. Prevalence of nonsyndromic oral clefts in a reference hospital in the state of Minas Gerais, Brazil, between 2000-2005. Martelli-Junior $H$, Porto LCVP, Barbosa DR, Bonan PRF, Freitas AB, Coletta RD. Braz Oral Res. 2007 OctDec;21(4):314-7. PMID:18060257 [PubMed indexed for MEDLINE]

7. Unraveling human cleft lip and palate research Vieira AR. J Dent Res. 2008 Feb;87(2):119-25. PMID:18218836 [PubMed - indexed for MEDLINE]

8. The current understanding of cleft lip malformations. Wantia N, Rettinger G. Facial Plast Surg. 2002 Aug;18(3):147-53. PMID:12152133 [PubMed - indexed for MEDLINE]

9. The complex genetics of cleft lip and palate. Cobourne MT. Eur J Orthod. 2004 Feb;26(1):716. PMID:14994877 [PubMed - indexed for MEDLINE]

10. Cleft lip and palate: synthesizing genetic and environmental influences. Dixon M, ML, Beaty TH,Murray JC. Nat Rev Genet. 2011 March; 12(3): 167-178. PMID:21331089 [PubMed - indexed for MEDLINE]

11. Zeiger JS, Beaty TH (2002) Gene-environment interaction and risk to oral clefts. In: Wyszynski DF editors. Cleft lip and palate: from origin to treatment. New York: Oxford University Press; pp. 283-289.

12. Frequency of congenital craniofacial malformations in a Brazilian Reference Center. Paranaiba LMR, Miranda RT, Ribeiro LA, Barros LM, Martelli-Júnior H. Rev Bras Epidemiol. 2011;14:151-160.

13. Risk of cancer in relatives of children born with isolated cleft lip and palate. Vieira AR, Khaliq S, Lace B. Am J Med Genet A. 2012 Jun;158A(6):1503-4. Epub 2012 May 14. PMID:22585460 [PubMed - indexed for MEDLINE]

14. AXIS inhibition protein 2, orofacial clefts and a family history of cancer. Menezes R, Marazita ML, Goldstein McHenry T, Cooper ME, Bardi K, Brandon C, Letra A, Martin RA, Vieira AR. J Am Dent Assoc. 2009 Jan;140(1):80-4. PMID:19119171 [PubMed - indexed for MEDLINE]

15. Do parents of children with congenital malformations have a higher cancer risk? A nationwide study in Denmark. Zhu JL, Basso O, Hasle $\mathrm{H}$, Winther JF, Olsen JH, Olsen J. Br J Cancer. 2002 Aug 27;87(5):524-8. PMID:12189550 [PubMed - indexed for MEDLINE]

16. Cleft lip/palate and $\mathrm{CDH} 1 / \mathrm{E}$-cadherin mutation in families with hereditary diffuse gastric cancer. Frebourg T, Oliveira C, Hochain P, Karam R, Manouvrier S, Graziadio $C$, Vekemans M, Hartmann A, Baert-Desurmont S, Alexandre C, Lejeune Dumoulin S,Marroni C, Martin C, Castedo S, Lovett M, Winston J, Machado JC, Attié T, Jabs EW, Cai J, Pellerin P, Triboulet JP, Scotte M, Le Pessot F, Hedouin A, Carneiro F, Blayau M, Seruca R. J Med Genet. 2006 Feb;43(2):138-42. Epub 2005 Apr 14. 
17. Defining predictors of cleft lip and palate risk. Yildirim, Seymen F, Deeley K, Cooper ME, Vieira AR. J Dent Res. 2012 Jun;91(6):556-61. Epub 2012 Apr 10. PMID:22496123 [PubMed - indexed for MEDLINE]

18. Family history of cleft lip and palate in subjects diagnosed with leukemia. Jindal A, Vieira AR. Am J Med Genet A. 2012 Mar;158A(3):6789.Epub 2012 Feb 2. PMID:22302642 [PubMed indexed for MEDLINE]

19. Alderson P, Green S, Higgins JPT, editors. Cochrane Reviewers' Handbook 4.2.2 [updated March 2004]. In: The Cochrane Library, Issue 1 , 2004. Chichester, UK: John Wiley \& Sons, Ltd.

20. The strengthening the reporting of observational studies in epidemiology (STROBE) statement: guidelines for reporting observational studies. von Elm E, Altman DG, Egger M, Pocock SJ, Gøtzche PC, Vanderbroucke JP. BMJ. 2007 Oct 20;335(7624):806-8. PMID:17947786 [PubMed - indexed for MEDLINE]

21. Nonsyndromic cleft lip and palate is not associated with cancer or other birth defects. Steinwachs EF, Amos C, Johnston D, Mulliken J, Stal S, Hecht JT Am J Med Genet. 2000 Jan 3;90(1):17-24 PMID:10602112 [PubMed - indexed for MEDLINE]

22. Major hematological diseases associated with cleft lip and palate. Lin CH, Lo LJ, Wang ML, Chen YR, Noordhoff MS. Cleft Palate Craniofac J. 2000 Sep;37(5):512-5. PMID:11034036 [PubMed - indexed for MEDLINE]

23. Mossey P, Little J (2002) Epidemiology of oral clefts: an international perspective. In: Wyszynski DF, editors. Cleft lip and palate: from origin to treatment. New York: Oxford University Press.pp 127-158.

24. Maternal use of antibiotics and the risk of orofacial clefts: a nationwide cohort study. Mølgaard-Nielsen, Hviid A. Pharmacoepidemiol Drug Saf. 2012 Mar;21(3):246-53. Epub 2011 Nov 28. PMID: 22125260 [PubMed - indexed for MEDLINE]

25. Cancer risk in persons with oral cleft - a population-based study of 8,093 cases. Bille C, Winther JF, Bautz A, Murray JC, Olsen J, Christensen K. Am J Epidemiol. 2005 Jun 1;161(11):1047-55. PMID:15901625 [PubMed indexed for MEDLINE]

26. Nevoid basal cell carcionoma syndrome with cleft lip and palate associated with the novel PTCH gene mutations. Sasaki R, Saito $K$, Watanabe $\mathrm{Y}$, Yoshinaga T, Fujii K, Agawa K, Miyashita T, Ando T, Akizuki T. J Hum Genet. 2009 Jul;54(7):398-402. Epub 2009 Jun 12. PMID: 19521425 [PubMed - indexed for MEDLINE]

27. Cleft lip and palate in Puerto Rico: A Thirtythree year study. Oliver-Padilla G, MartínezGonzález V. Cleft Palate J. 1986 Jan;23(1):48-57. PMID:3455903 [PubMed - indexed for MEDLINE]

28. Incidence of cleft lip, cleft palate, and cleft lip and palate among races: a review. Vanderas AP. Cleft Palate J.1987 Jul;24(3):216-25.
PMID:3308178 [PubMed - indexed for MEDLINE]

29. The genetics of isolated orofacial clefts: from genotypes to subphenotypes. Jugessur A, Farlie PG, Kilpatrick N. Oral Dis. 2009 Oct;15(7):43753. Epub 2009 Jul 2. PMID:19583827 [PubMed indexed for MEDLINE]

30. Hereditary cleft lip/palate and Will Tumor: A rare association. Yu CC, Wong FH, Lo $L$, Chen YR. Cleft Palate Craniofac J. 2002 May;39(3):376-9. PMID:12019017 [PubMed indexed for MEDLINE]

31. Gene/environment causes of cleft lip and/or palate. Murray JC. Clin Genet. 2002 Apr;61(4):248-56. PMID:12030886 [PubMed indexed for MEDLINE]

32. Cleft lip (+/- cleft palate) in Danish twins, 19701990. Christensen K, Fogh-Andersen P. Am J Med Genet. 1993 Nov 1;47(6):910-6. PMID:8279491 [PubMed - indexed for MEDLINE]

33. Analysis of family incidence of cleft lip and/or palate. Kot M, Kruk-Jeromini J. Med Sci Monit. $2007 \quad$ May;13 (5):CR231-4. PMID:17476195 [PubMed - indexed for MEDLINE]

34. A population-based study of cancer incidence in twins and in children with congenital malformations or low birth weight, Norway, 19671980. Windham GC, Bjerkedal T, Langmark F. Am J Epidemiol. 1985 Jan;121(1):49-56. PMID:3155484 [PubMed - indexed for MEDLINE]

35. Increased prevalence of minor anomalies in childhood malignancy. Mehes K, Signer E, Pluss HJ, Müller HJ, Stalder G. Eur J Pediatr. 1985 Sep;144(3):243-54. PMID:4054163 [PubMed indexed for MEDLINE]

36. Excess of mild errors of morphogenesis in childhood lymphoblastic leukemia. Mehes K, Kajtar P, Sandor G, Scheel-Walter M, Niethammer D. Am J Med Genet. 1998 Jan 6;75(1):22-7. PMID:9450852 [PubMed - indexed for MEDLINE]

37. Maternal and perinatal risk factors for childhood leukemia. Zack M, Adami HO, Ericson A. Cancer Res. 1991 Jul 15;51(14):3696-701. PMID: 2065325 [PubMed - indexed for MEDLINE]

38. Risk of childhood cancer for infants with birth defects, part I: a record-linkage study, Atlanta, Georgia, 1968-1988. Mili F, Khoury MJ, Flanders WD, Greenberg RS. Am J Epidemiol. 1993 Mar 15;137(6):629-38. PMID:8470664 [PubMed indexed for MEDLINE]

39. Congenital malformations and childhood cancer. Nishi M, Miyake H, Takeda T, Hatae Y. Med Pediatr Oncol. 2000;34:250-254.

40. Increased prevalence of minor anomalies in children with hematologic malignancies. Roganovic J, Radojcic-Badovinac A, Ahel V. Med Pediatr Oncol. 2002 Feb;38(2):128-30. PMID:11813182 [PubMed - indexed for MEDLINE].

41. Infant leukemia and congenital abnormalities: a children's oncology group study. Johnson KJ,
Roesler MA, Linabery AM, Hilden JA, Davies SM, Ross JA. Pediatr Blood Cancer. 2010 Jul;55(1):95-9. PMID:20486175 [PubMed - indexed for MEDLINE]

42. Hypodontia as a risk marker for epithelial ovarian cancer: a case-controlled study. Chalothorn LA, Beeman CS, Ebersole JL, Kluemper GT, Hicks EP, Kryscio RJ, DeSimone CP, Modesitt SC. J Am Dent Assoc. 2008 Feb;139(2):163-9. PMID:18245684 [PubMed - indexed for MEDLINE]

43. Tooth agenesis association with selfreported family history of cancer. Küchler EC, Lips A, Tannure PN, Ho B, Costa MC, Granjeiro JM, Vieira AR. J Dent Res. 2013 Feb;92(2):149-55. Epub 2012 Nov 20. PMID:23169889 [PubMed - indexed for MEDLINE]

44. Disruption of an AP-2alpha binding site in an IRF6 enhancer is associated with cleft lip. Rahimov F, Marazita M, Visel A, Cooper M, Hitchler $M$, Rubini $M$, Domann $F E$, Govil $M$, Christensen K, Bille $C$, Melbye $M$, Jugessur A, Lie RT, Wilcox AJ, Fitzpatrick DR, Green ED, Mossey PA, Little J, Steegers-Theunissen RP, Pennacchio LA, Schutte BC, Murray JC. Nat Genet. 2008 Nov;40(11):1341-7. Epub 2008 Oct 5. PMID:18836445 [PubMed - indexed for MEDLINE].

45. A cohort study of recurrence patterns among more than 54,000 relatives of oral cleft cases in Denmark: Support for the multifactorial threshold model of inheritance. Grosen D, Chevrier C, Skytthe A, Bille C, Mølsted K, Sivertsen A, Murray JC, Christensen K. J Med Genet. 2010 Mar;47(3):162-8.Epub 2009 Sep 14. PMID:19752161 [PubMed - indexed for MEDLINE] 